\title{
KEEFEKTIFAN MODEL PEMBELAJARAN KOOPERATIF TIPE GROUP INVESTIGATION (GI) DAN INQUIRY DALAM PEMBELAJARAN IPA KELAS V SD
}

\author{
Supriyati \& Mawardi \\ mawardiu@gmail.com \\ Pendidikan Guru Sekolah Dasar - FKIP - UKSW Salatiga
}

\begin{abstract}
ABSTRAK
Penelitian ini bertujuan untuk mengetahui ada tidaknya perbedaan keefektifan model pembelajaran Group Investigation (GI) dengan model pembelajaran Inquiry ditinjau dari hasil belajar IPA siswa kelas V SD Gugus Maruto Bawen. Jenis penelitian yang digunakan dalam penelitian ini adalah penelitian eksperimen semu (quasi eksperimental research) dengan desain nonequivalent control group design. Subjek penelitian dalam penelitian ini adalah siswa kelas V SD N Samban 02 (SD imbas) dan VC SDIP H. Soebandi (SD swasta) sebagai kelompok eksperimen serta siswa kelas V SD N Samban 01 (SD imbas) dan VB SDIP H. Soebandi (SD swasta) sebagai kelompok kontrol. Variabel dalam penelitian ini terdiri dari model Group Investigation dan Inquiry sebagai variabel bebas dan hasil belajar sebagai variabel terikat. Pengumpulan data dilakukan dengan menggunakan instrumen soal tes dan lembar observasi. Teknik analisis data menggunakan uji Independent Sample T Test yang dikenakan pada skor posttest dan gain score. Hasil penelitian menunjukkan bahwa nilai t hitung $-1,182$ dan t tabel 1,985 dengan signifikansi 0,240. Hasil uji t gain score kelompok eksperimen dan kontrol menunjukkan t hitung 0,468 dan t tabel 1,985 dengan signifikansi 0,641. Karena nilai signifikansi $>0,05$ dan $t$ hitung $<\mathrm{t}$ tabel maka $\mathrm{H}_{0}$ diterima yaitu tidak ada perbedaan hasil belajar yang signifikan dalam penerapan model pembelajaran kooperatif tipe Group Investigation dan Inquiry ditinjau dari hasil belajar IPA siswa kelas V SD Gugus Maruto Bawen. Maknanya bahwa tidak terdapat perbedaan keefektifan model pembelajaran Group Investigation dan Inquiry dalam pembelajaran IPA di kelas V SD Gugus Maruto. Saran berkenaan dengan temuan penelitian ini adalah guru dapat menggunakan model pembelajaran kooperatif tipe Group Investigation (GI) atau Inquiry dalam pembelajaran IPA sebagai alternatif untuk meningkatkan hasil belajar siswa, yang disesuaikan dengan karakteristik siswa.
\end{abstract}

Kata kunci: Group Investigation, Inquiry, Hasil Belajar, Pembelajaran IPA. 


\section{PENDAHULUAN}

Pembelajaran IPA pada hakikatnya adalah scientific inquiry, yaitu pemberian pengalaman belajar secara langsung melalui penggunaan dan pengembangan ketrampilan proses dan sikap ilmiah. Sehingga di dalam pembelajaran IPA di SD diperlukan model pembelajaran inovatif, sehingga siswa mengalami/berbuat dan menemukan pengetahuannya sendiri dengan bimbingan dari guru. Model pembelajaran yang inovatif dan variatif diperlukan untuk menunjang ketercapaian dari tujuan pembelajaran IPA yang diharapkan. Karena pemilihan model pembelajaran yang tepat akan mampu menarik perhatian siswa untuk ikut aktif mengikuti proses pembelajaran. Siswa yang aktif mengikuti proses pembelajaran akan berusaha mengembangkan segala potensi yang dimilikinya guna mencapai tujuan pembelajaran yang diharapkan.

Namun kenyataan di lapangan menunjukkan hal yang berbeda, sebagian besar guru masih menggunakan cara-cara lama seperti menggunakan metode ceramah dan tanya jawab dalam memberikan pengalaman belajar kepada siswa, sehingga tujuan pembelajaran yang diharapkan tidak tercapai. Berdasarkan observasi di lapangan melalui wawancara dengan guru kelas V di SD Negeri Samban 02 (SD Imbas Gugus Maruto), tingkat keaktifan siswa dalam mengikuti pembelajaran IPA hanya mencapai $40 \%$ dan pembelajaran masih terpusat pada guru (teacher centered).

Dilihat dari sisi guru, fenomena rendahnya keaktifan belajar siswa karena guru belum sering menerapkan metode pembelajaran yang inovatif, guru masih mendominasi pembelajaran dengan metode ceramah, tanya jawab, praktek/percobaan walaupun pernah juga diterapkan model pembelajaran Jigsaw. Hal ini pada akhirnya berpengaruh terhadap hasil belajar yang diterima siswa, yaitu tingkat ketuntasan belajar siswa sekitar 70-75\% dari jumlah siswa sebanyak 27 orang dengan KKM 65.

Hal serupa juga nampak ketika dilakukan observasi lapangan di salah satu SD swasta di Gugus Maruto, yaitu di SDIP H. Soebandi. Berdasarkan wawancara yang dilakukan dengan guru kelas $\mathrm{V}$ di SD tersebut diperoleh data bahwa tingkat ketuntasan belajar siswa pada mata pelajaran IPA dengan KKM 70 hanya mencapai $75 \%$ dari jumlah siswa sebanyak 20 orang. Namun berbeda dengan SD Negeri, SD swasta di Gugus Maruto sudah mampu menerapkan model pembelajaran yang inovatif seperti $P B L$ dan Discovery Learning. Meskipun demikian guru masih menerapkan metode ceramah, karena bagaimanapun metode ceramah tetap dibutuhkan.

Ditinjau dari kondisi riil di lapangan, terjadi suatu kesenjangan antara kondisi ideal dan kondisi riil di Gugus Maruto yang menyebabkan timbulnya suatu masalah, yaitu kesenjangan ketuntasan hasil belajar siswa sebesar 25-30\%. Oleh 
Keefektifan Model Pembelajaran Kooperatif tipe Group Investigation (GI) Dan Inquiry (Supriyati \& Mawardi)

karena itu diperlukan suatu treatment dalam pembelajaran berupa penerapan model pembelajaran inovatif. Ada berbagai model pembelajaran inovatif yang secara potensial dapat meningkatkan kemampuan siswa dalam menguasai kompetensi IPA diantaranya Problem Based Learning (PBL), Discovery Learning, Problem Solving, SAVI, Group Investigation, Think Talk Write (TTW), Make A Match, Pair Checks, Course Review Horay, Snowball Throwing, Inquiry dan Debate.

Dari berbagai model pembelajaran tersebut, model pembelajaran kooperatif yang dirasa sesuai dan dapat digunakan dalam pembelajaran IPA adalah model pembelajaran Group Investigation (GI) dan Inquiry. Keduanya mempunyai kesamaan yaitu mengandung unsur penemuan dalam proses pembelajarannya. Selain itu model pembelajaran kooperatif tipe GI dan Inquiry ini sesuai dengan karakteristik siswa SD yaitu suka berkelompok. Dengan berkelompok mereka akan lebih mudah dalam menyelesaikan suatu tugas karena dikerjakan secara bersamasama. Oleh karena itu dalam penelitian ini dirumuskanlah masalah, "apakah terdapat perbedaan keefektifan model pembelajaran Group Investigation (GI) dengan model pembelajaran Inquiry ditinjau dari hasil belajar IPA pada siswa kelas V SD Gugus Maruto Bawen".

Tujuan dari penelitian ini adalah untuk mengetahui apakah terdapat perbedaan keefektifan model pembelajaran Group Investigation (GI) dengan model pembelajaran Inquiry ditinjau dari hasil belajar IPA siswa kelas V SD Gugus Maruto Bawen. Penelitian ini diharapkan memberikan manfaat praktis dan teoritis. Manfaat teoritisnya adalah dapat memberikan masukan untuk pengembangan ilmu pengetahuan. Sedangkan manfaat praktisnya ditujukan kepada siswa, guru dan sekolah. Bagi siswa diharapkan adanya peningkatan keaktifan dan hasil belajar. Bagi guru diharapkan lebih kreatif dan inovatif dalam merencanakan, memilih dan menerapkan model pembelajaran. Bagi sekolah diharapkan dapat meningkatkan kualitas pembelajaran di SD Gugus Maruto.

\section{KAJIAN PUSTAKA}

\section{Hakikat IPA}

Latar belakang dari Pembelajaran IPA menurut KTSP Standar Isi 2006 adalah Pendidikan IPA diharapkan dapat menjadi wahana bagi peserta didik untuk mempelajari diri sendiri dan alam sekitar, serta prospek pengembangan lebih lanjut dalam menerapkannya di dalam kehidupan sehari-hari. Sehingga dari latar belakang ini pembelajaran IPA mempunyai pengaruh penting dalam kehidupan manusia pada umumnya. Karena dengan adanya pembelajaran IPA ini, manusia akan termotivasi untuk melakukan penemuan dan inovasi untuk menunjang kehidupannya.

IPA diperlukan dalam kehidupan sehari-hari untuk memenuhi kebutuhan manusia melalui pemecahan masalah-masalah yang dapat diidentifikasikan. 
Penerapan IPA perlu dilakukan secara bijaksana agar tidak berdampak buruk terhadap lingkungan. Di tingkat SD diharapkan ada penekanan pembelajaran Salingtemas (Sains, lingkungan, teknologi, dan masyarakat) yang diarahkan pada pengalaman belajar untuk merancang dan membuat suatu karya melalui penerapan konsep IPA dan kompetensi bekerja ilmiah secara bijaksana.

\section{Model Pembelajaran Group Investigation (GI)}

Investigasi menurut Krismanto (dalam Utami, 2012:110) merupakan kegiatan pembelajaran yang memberikan kemungkinan siswa untuk mengembangkan pemahaman siswa melalui berbagai kegiatan dan hasil belajar sesuai dengan pengembangan yang dilalui siswa. Eggen dan Kauchak (dalam Karnawati, 2013) berpendapat Group Investigation adalah suatu pembelajaran kooperatif yang menempatkan siswa ke dalam kelompok untuk melakukan investigasi terhadap suatu topik.

Slavin (dalam Setyorini, 2014:8) menyatakan Group Investigation adalah sebuah perencanaan kelas secara umum dimana siswa bekerja dalam kelompok kecil dengan menggunakan inkuiri kooperatif diskusi kelompok dan perencanaan kooperatif. Jadi dapat disimpulkan bahwa model pembelajaran kooperatif tipe Group Investigation merupakan model kegiatan pembelajaran yang bersifat demokratis yang diwujudkan dalam bentuk kooperatif diskusi kelompok, yang terdiri dari beberapa kelompok kecil untuk menginvestigasi pemecahan suatu masalah.

Sintagmatik atau struktur model pembelajaran GI menurut Joyce, Weil dan Calhoun (2009:318) yaitu tahap pertama, menyajikan situasi yang rumit (terencana atau tidak terencana). Guru menyajikan sebuah masalah yang memancing perhatian dan kehebohan siswa. Penyajian masalah tersebut dapat dilakukan secara verbal dalam bentuk cerita pengalaman atau dapat juga melalui penayangan video/gambar. Dalam kaitan dengan materi pembelajaran yaitu jenis-jenis tanah, masalah disajikan dalam bentuk percobaan dan menunjukkan gambar tentang komposisi penyusun tanah.

Tahap kedua, menjelaskan dan menguraikan reaksi terhadap situasi. Jika siswa bereaksi terhadap masalah yang disajikan, guru menggiring perhatian mereka terhadap reaksi mereka masing-masing yang berbeda, yakni meliputi sikap yang mereka tunjukkan, apa yang mereka rasakan, dan bagaimana mereka mengatur sesuatu. Misalnya ketika ada siswa yang bertanya mengenai masalah yang disajikan dalam pertunjukkan percobaan dan gambar, guru tidak langsung memberikan jawaban yang pasti, tetapi mengarahkan mereka untuk mencari jawaban sendiri melalui investigasi kelompok.

Tahap ketiga, merumuskan tugas dan mengaturnya dalam pembelajaran. Ketika siswa mulai tertarik terhadap perbedaan reaksi dari masing-masing individu, 
Keefektifan Model Pembelajaran Kooperatif tipe Group Investigation (GI) Dan Inquiry (Supriyati \& Mawardi)

guru menggiring mereka untuk merumuskan dan menyusun masalah-masalah bagi diri mereka sendiri. Misalnya saat seorang siswa mengetahui reaksi yang berbeda dari siswa lain, misalnya berupa bentuk pertanyaan yang berbeda, siswa mulai tertarik dengan keberagaman reaksi tersebut, maka guru segera mengambil tindakan untuk mengarahkan mereka untuk merumuskan dan menyusun masalah lain yang timbul dari masing-masing individu dengan menuliskan daftar masalah di papan tulis.

Tahap keempat, studi yang mandiri dan berkelompok. Siswa dalam kelompok menganalisis beberapa peran yang dibutuhkan, mengatur diri mereka sendiri berdasarkan peran yang didapatkan, bertindak, dan melaporkan hasil yang didapatkan. Setelah siswa mengetahui beberapa masalah yang timbul dari masingmasing individu melalui daftar masalah yang sudah ditulis, kemudian siswa mengelompokkan diri berdasarkan minat mereka terhadap masalah tersebut dan bekerja bersama kelompoknya sesuai peran yang didapatkannya, misalnya dia mendapat peran untuk menyelidiki tentang ciri-ciri jenis tanah liat. Setelah selesai kemudian kelompok mempresentasikan hasil yang didapatkan dalam kegiatan investigasi di hadapan kelompok lain.

Tahap kelima, menganalisis perkembangan dan proses. Masing-masing kelompok mengevaluasi solusi permasalahan yang dicocokkan dengan maksud dan tujuan utama. Dalam mempresentasikan hasil investigasi, kelompok lain bertugas sebagai pengontrol apakah hasil investigasinya sudah tepat atau belum dengan bimbingan dari guru. Hasil investigasi disesuaikan dengan tujuan utama dari permasalahan yang dimunculkan. Tahap keenam, mendaur ulang aktivitas. Beberapa tahapan terus berlanjut, baik dengan penyajian masalah yang sama atau memunculkan masalah baru yang merangsang adanya investigasi. Hal ini dilakukan apabila terdapat masalah yang membutuhkan penyelidikan lebih lanjut.

\section{Model Pembelajaran Inquiry}

Ada beberapa pendapat mengenai pengertian model pembelajaran Inquiry dalam Soewarso (2013:3) yaitu diantaranya Richard Suchman mengemukakan bahwa model Inquiry adalah suatu pola yang membantu peserta didik belajar merumuskan dan menguji pendapatnya sendiri dan memiliki kesadaran akan kemampuannya. Sedangkan Antony S. Jones berpendapat bahwa model Inquiry adalah strategi mengajar yang memungkinkan para peserta didik mendapatkan jawabannya sendiri.

Model Inquiry menurut Sumantri adalah cara penyajian pelajaran yang memberi kesempatan kepada peserta didik untuk menentukan informasi dengan atau tanpa bantuan guru. Ciri khusus dari model Inquiry adalah siswa atau peserta didik mampu merumuskan dan menguji jawabannya sendiri melalui sebuah penelitian. Jadi dapat disimpulkan bahwa model pembelajaran Inquiry adalah model 
pembelajaran yang memungkinkan siswa untuk merumuskan dan menguji jawabannya sendiri dengan atau tanpa bantuan guru melalui sebuah penelitian.

Sintagmatik atau struktur model pembelajaran Inquiry menurut Joyce, Weil dan Calhoun (2009:206-208) yaitu: tahap pertama, orientasi atau mengenalkan masalah. Pada tahap ini guru menyajikan situasi permasalahan dan menjelaskan prosedur-prosedur penelitian. Situasi permasalahan dapat disajikan dalam bentuk cerita yang disampaikan secara verbal maupun melalui pertunjukkan suatu percobaan atau sebuah gambar. Dalam kaitan dengan materi pembelajaran yaitu jenis-jenis tanah, masalah disajikan dalam bentuk percobaan dan menunjukkan gambar tentang komposisi penyusun tanah.

Tahap kedua, verifikasi pengumpulan data. Siswa mencoba mengumpulkan data yang berkaitan dengan masalah yang diajukan. Verifikasi data dapat dilakukan dengan cara mengajukan serangkaian pertanyaan yang memungkinkan guru dapat menjawab dengan kata ya atau tidak. Dalam tahap ini siswa mulai membentuk kelompok, membuat hipotesis mengenai data yang mereka kumpulkan dan dapat bertanya pada guru mengenai hipotesis yang mereka buat dengan pertanyaan yang terbatas pada jawaban ya atau tidak.

Tahap ketiga, eksperimentasi pengumpulan data. Siswa melakukan serangkaian uji coba terhadap situasi permasalahan berdasarkan pengumpulan data yang sudah diverifikasi. Eksperimentasi memiliki dua fungsi, yaitu eksplorasi dan pengujian langsung. Dalam tahap ini siswa bekerja dalam kelompok untuk melakukan percobaan tentang ciri-ciri dari masing-masing jenis tanah dan sekaligus untuk menguji hipotesis yang telah mereka buat.

Tahap keempat, mengolah dan merumuskan penjelasan. Siswa mengolah informasi yang mereka dapatkan selama pengumpulan data dan mencoba menjelaskan ketidaksesuaian-ketidaksesuaian atau perbedaan-perbedaan. Setelah berhasil menguji hipotesis melalui percobaan tentang ciri-ciri berbagai jenis tanah siswa bekerja dalam kelompok untuk mengolah data dan menyusunnya dalam bentuk laporan sederhana.

Tahap kelima, menganalisis proses penelitian. Siswa menganalisis strategistrategi pemecahan masalah yang telah mereka gunakan selama penelitian. Dalam tahap ini terlebih dahulu siswa menyampaikan hasil laporan masing-masing kemudian melaksanakan diskusi kelas dengan melibatkan guru untuk menganalisis proses penelitian yang sudah dilakukan agar diketahui bagian/tahapan mana yang masih sulit dilaksanakan siswa. 
Keefektifan Model Pembelajaran Kooperatif tipe Group Investigation (GI) Dan Inquiry (Supriyati \& Mawardi)

\section{Hasil Belajar}

Indikator untuk mengetahui tercapainya suatu tujuan pembelajaran salah satunya adalah dengan melakukan pengukuran terhadap hasil belajar. Hasil belajar menjadi puncak dari suatu proses pembelajaran. Hasil belajar tidak hanya terbatas pada aspek kognitif tetapi dapat juga dalam aspek afektif dan psikomotorik.

Hasil belajar menurut Nana Sudjana (2005:22) adalah kemampuankemampuan yang dimiliki siswa setelah ia menerima pengalaman belajarnya. Horward Kingsley (dalam Sudjana, 2005:22) mengklasifikasikan hasil belajar menjadi 3 macam, yaitu ketrampilan dan kebiasaan, pengetahuan dan pengertian, sikap dan cita-cita. Hal tersebut senada dengan Benyamin Bloom yang membagi kriteria hasil belajar menjadi 3 ranah yaitu ranah kognitif, ranah afektif dan psikomotoris.

Dimyati (dalam Setyorini, 2014:9) berpendapat bahwa hasil belajar adalah hasil dari suatu interaksi tindakan belajar dan tindakan mengajar. Winkel (dalam Setyorini, 2014:8) juga berpendapat bahwa hasil belajar merupakan salah satu bukti yang menunjukkan kemampuan atau keberhasilan seseorang yang melakukan proses belajar sesuai bobot atau nilai yang berhasil diraihnya. Sehingga dapat disimpulkan bahwa hasil belajar adalah hasil/bukti keberhasilan siswa dalam mengikuti proses pembelajaran berupa kemampuan-kemampuan yang dimiliki dari segi kognitif, afektif, dan psikomotorik. Sebagian besar guru melakukan penilaian hasil belajar dari segi kognitif, yaitu melalui tes tertulis maupun lisan, baik tes formatif maupun tes sumatif.

Keefektifan model pembelajaran Group Investigation dalam penelitian ini dapat dilihat dari ketuntasan perolehan hasil belajar IPA pada materi jenis-jenis tanah dengan menggunakan model Group Investigation dan Inquiry. Pengukuran hasil belajar tersebut diperoleh dengan menggunakan teknik tes berupa tes sumatif dalam bentuk pilihan ganda.

Berdasarkan petunjuk pelaksanaan proses belajar mengajar Depdikbud (dalam Mawardi dan Puspasari, 2011:203) terdapat kriteria ketuntasan belajar perorangan dan klasikal yaitu: 1) Seorang siswa dikatakan telah tuntas belajar jika siswa tersebut telah mencapai skor $65 \%$ atau nilai 65.2 ) Suatu kelas dikatakan tuntas belajar jika terdapat $85 \%$ siswa yang telah mencapai daya serap lebih dari atau sama dengan 65\%. Jadi acuan untuk mengetahui keefektifan model pembelajaran bila masing-masing siswa mencapai nilai ketuntasan minimal 65 atau tuntas secara klasikal bila terdapat 85\% siswa yang tuntas dengan KKM 65 . 
Scholaria, Vol. 5, No. 2, Mei 2015: 80 - 96

\section{Kerangka pikir}

Berikut bagan komparasi kerangka berpikir model GI dan Inquiry.

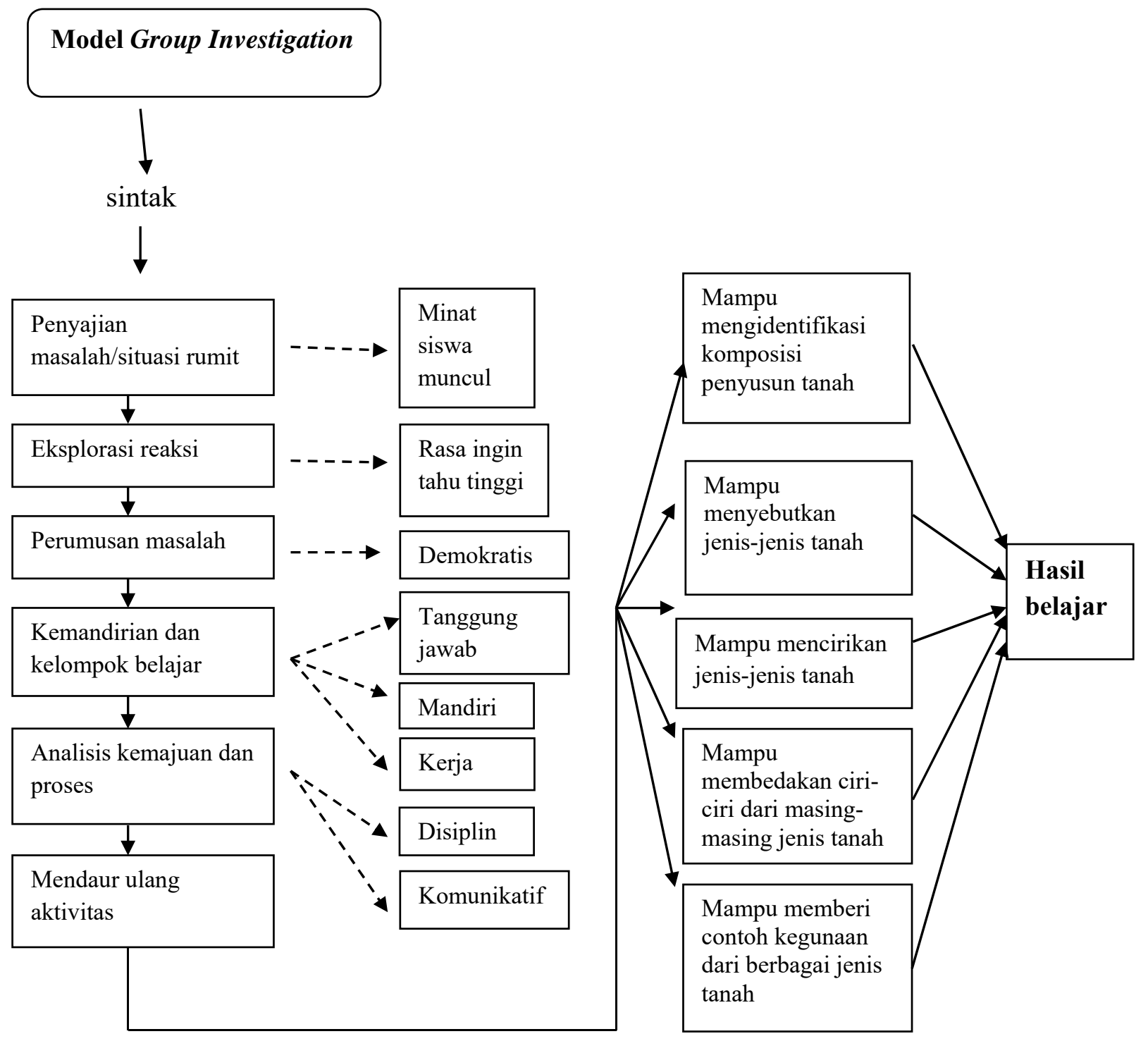

Gambar 1. Bagan kerangka berpikir model Group Investigation

Keterangan:

Dampak instruksional

Dampak pengiring 
Keefektifan Model Pembelajaran Kooperatif tipe Group Investigation (GI) Dan Inquiry (Supriyati \& Mawardi)

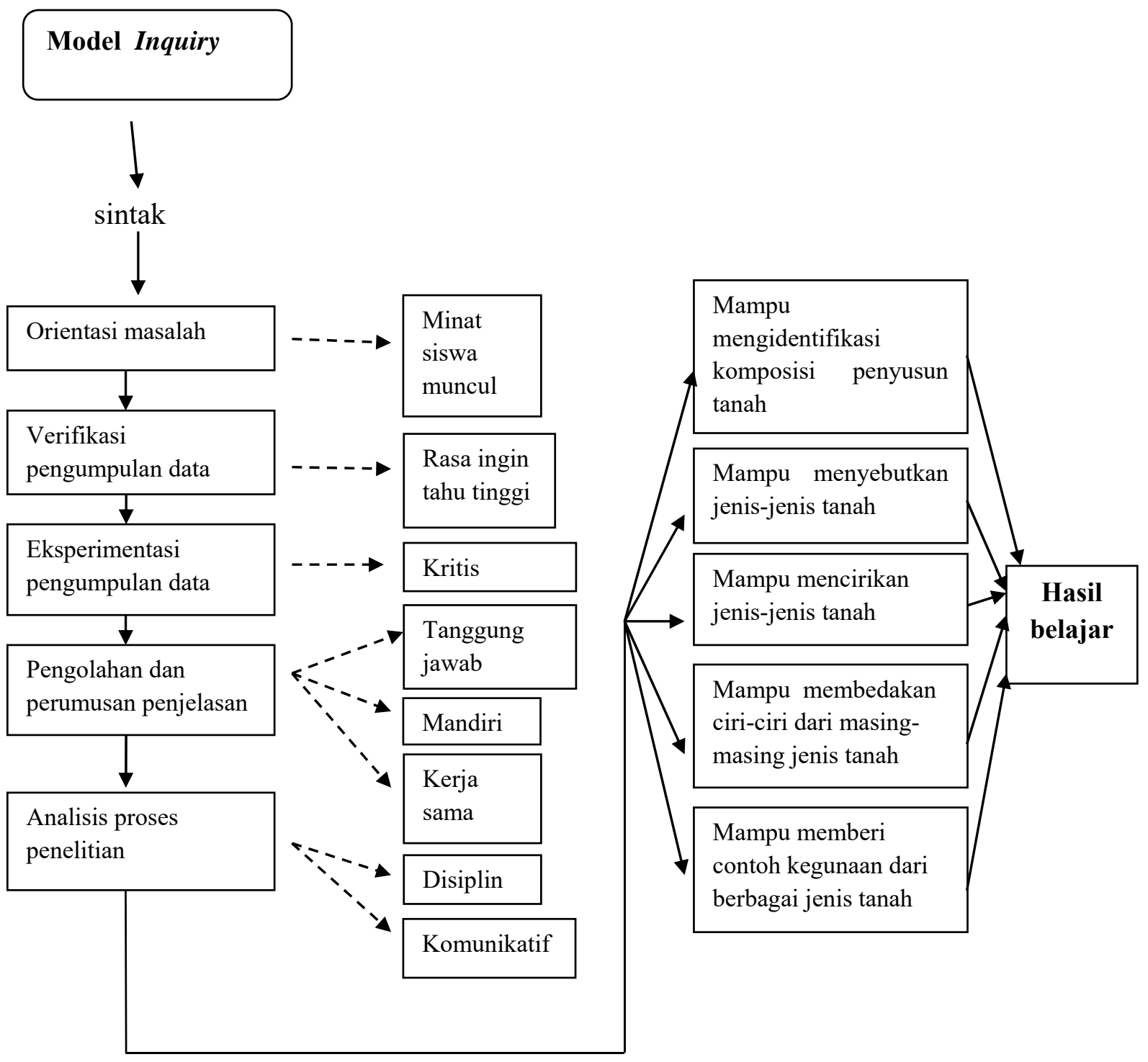

Gambar 2. Bagan kerangka berpikir model Inquiry

\section{Keterangan}

Dampak instruksional

Dampak pengiring

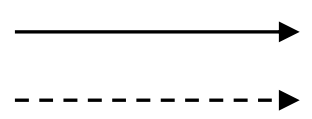

Berdasarkan kajian pustaka dan kerangka berpikir tersebut, maka dirumuskanlah hipotesis penelitian sebagai berikut: 
$\mathrm{H}_{0}$ : Tidak ada perbedaan hasil belajar IPA yang signifikan dalam penerapan model pembelajaran kooperatif tipe Group Investigation dan Inquiry pada siswa kelas V SD Gugus Maruto Bawen.

$\mathrm{H}_{\mathrm{a}}$ : Ada perbedaan hasil belajar IPA yang signifikan dalam penerapan model pembelajaran kooperatif tipe Group Investigation dan Inquiry pada siswa kelas V SD Gugus Maruto Bawen.

\section{METODE PENELITIAN}

Jenis penelitian yang digunakan dalam penelitian ini adalah penelitian eksperimen semu (quasi eksperimental research) dengan Nonequivalent Control Group Design sebagai desainnya. Penelitian ini dilakukan di SD Gugus Maruto yang terletak di wilayah Kecamatan Bawen Kabupaten Semarang Jawa Tengah. Populasi siswa kelas V di SD Gugus Maruto berjumlah 252 siswa, karena jumlah tersebut terhitung banyak maka diambillah sampel dengan menggunakan teknik cluster sampling, yaitu dengan memilih perwakilan dari SD swasta dan imbas. Sampel tersebut kemudian dijadikan sebagai subjek penelitian yang perinciannya pada tabel berikut ini.

Tabel 1. Daftar Subjek Penelitian

\begin{tabular}{|c|l|c|c|c|l|}
\hline No. & Nama Sekolah & Status & Kelas & $\begin{array}{c}\text { Jumlah } \\
\text { Siswa }\end{array}$ & Kelompok \\
\hline 1. & $\begin{array}{l}\text { SD Negeri } \\
\text { Samban 01 }\end{array}$ & SD Imbas & V & 32 & Kontrol \\
\hline 2. & $\begin{array}{l}\text { SD Negeri } \\
\text { Samban 02 }\end{array}$ & SD Imbas & V & 26 & Eksperimen \\
\hline 3. & $\begin{array}{l}\text { SDIT H. } \\
\text { Soebandi }\end{array}$ & SD Swasta & VB & 21 & Kontrol \\
\cline { 4 - 6 } & \multicolumn{7}{|l}{ Jumlah keseluruhan } & 20 & Eksperimen \\
\hline \multicolumn{7}{|l}{}
\end{tabular}

Terdapat dua jenis variabel dalam penelitian ini yaitu, variabel bebas dan variabel terikat. Variabel bebas dalam penelitian ini adalah model pembelajaran Group Investigation dan Inquiry. Sedangkan variabel terikat dalam penelitian ini adalah hasil belajar IPA. Teknik pengumpulan data untuk mengukur variabel bebas yaitu dengan teknik observasi menggunakan instrumen lembar observasi. Sedangkan teknik pengumpulan data untuk mengukur variabel terikat dengan teknik tes menggunakan instrumen lembar soal tes yang terlebih dahulu diuji cobakan 
Keefektifan Model Pembelajaran Kooperatif tipe Group Investigation (GI) Dan Inquiry (Supriyati \& Mawardi)

untuk mengetahui tingkat validitas, reliabilitas dan kesukaran soal sebelum digunakan penelitian.

Berdasarkan hasil uji coba instrumen soal dari 37 soal diperoleh 15 soal valid dengan reliabilitas 0,853 , sedangkan tingkat kesukaran soal berada dalam kisaran mudah dan sedang. 15 soal valid inilah yang digunakan untuk penelitian. Teknik analisis data menggunakan uji normalitas, uji homogenitas, uji beda ratarata dan uji hipotesis. Uji normalitas dan homogenitas digunakan sebagai prasyarat untuk melakukan uji beda rata-rata dan uji hipotesis.

\section{HASIL PENELITIAN DAN PEMBAHASAN}

\section{Deskripsi Hasil Penelitian}

Hasil penelitian pada implementasi pembelajaran dengan model Group Investigation sebagai kelompok eksperimen dirangkum sebagai berikut. Berdasarkan hasil observasi proses pembelajaran IPA di kelas V SD Negeri Samban 02 (SD Negeri Imbas) diperoleh tingkat keterlaksanaan pengajar dalam melaksanakan sintak dari model pembelajaran Group Investigation mencapai 90\% dari 19 poin kegiatan. Sedangkan tingkat hasil belajarnya diperoleh nilai rata-rata pretest (sebelum perlakuan model Group Investigation) sebesar 60,42 dan nilai ratarata posttest (setelah perlakuan model Group Investigation) sebesar 71,38.

Hasil observasi proses pembelajaran IPA di kelas VC SDIP H. Soebandi (SD Swasta) diperoleh tingkat keterlaksanaan pengajar dalam melaksanakan sintak dari model pembelajaran Group Investigation mencapai 79\% dari 19 poin kegiatan. Sedangkan tingkat hasil belajarnya diperoleh nilai rata-rata pretest (sebelum perlakuan model Group Investigation) sebesar 72 dan nilai rata-rata posttest (setelah perlakuan model Group Investigation) sebesar 79,74.

Tidak jauh berbeda hasil penelitian pada implementasi pembelajaran dengan model Inquiry sebagai kelompok kontrol dirangkum sebagai berikut. Berdasarkan hasil observasi proses pembelajaran IPA di kelas V SD Negeri Samban 01 (SD Negeri Imbas) diperoleh tingkat keterlaksanaan pengajar dalam melaksanakan sintak dari model pembelajaran Inquiry mencapai $91 \%$ dari 22 poin kegiatan. Sedangkan tingkat hasil belajarnya diperoleh nilai rata-rata pretest (sebelum perlakuan model Inquiry) sebesar 66,69 dan nilai rata-rata posttest (setelah perlakuan model Inquiry) sebesar 74,59.

Hasil observasi proses pembelajaran IPA di kelas VB SDIP H. Soebandi (SD Swasta) diperoleh tingkat keterlaksanaan pengajar dalam melaksanakan sintak dari model pembelajaran Inquiry mencapai $87 \%$ dari 22 poin kegiatan. Sedangkan tingkat hasil belajarnya diperoleh nilai rata-rata pretest (sebelum perlakuan model Inquiry) sebesar 74,95 dan nilai rata-rata posttest (setelah perlakuan model Group Investigation) sebesar 82,71. 


\section{Deskripsi Komparasi Hasil Pengukuran}

Deskripsi komparasi pengukuran hasil belajar siswa kelompok eksperimen dan kelompok kontrol secara ringkas disajikan pada grafik berikut.

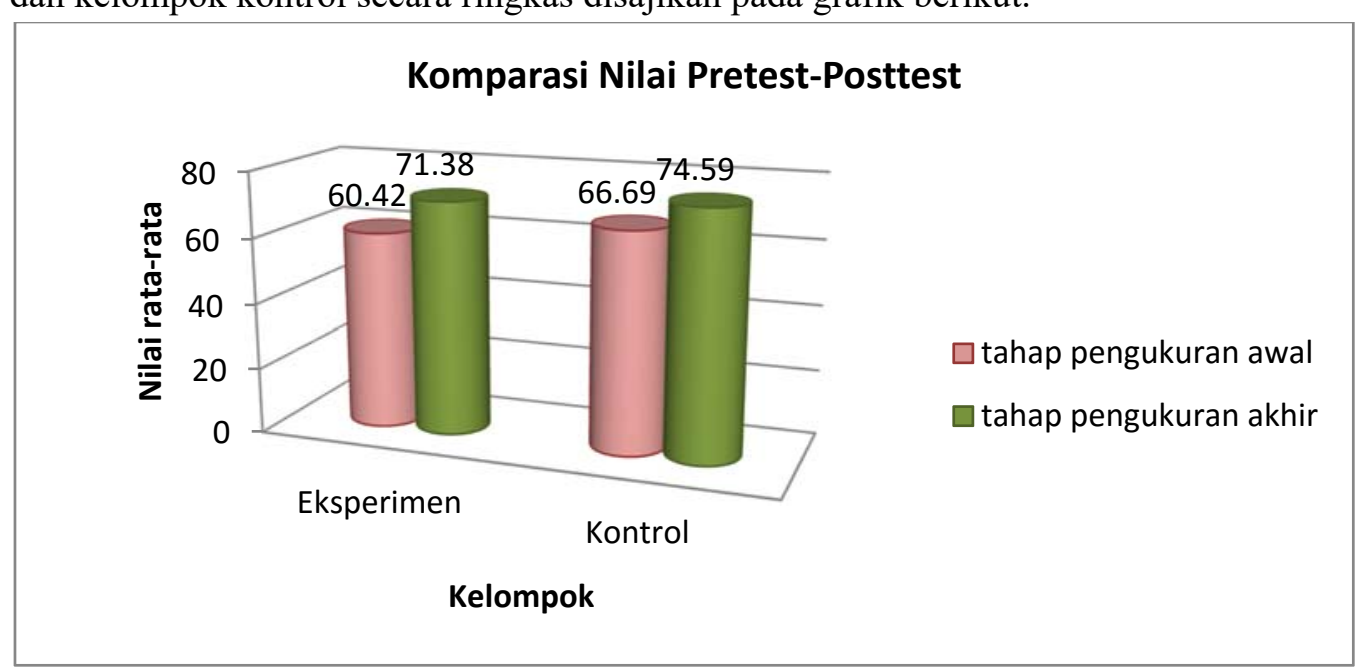

Gambar 3. Grafik Deskripsi Komparasi Hasil Pengukuran Kelompok Eksperimen dan Kelompok Kontrol SD Negeri Imbas Gugus Maruto

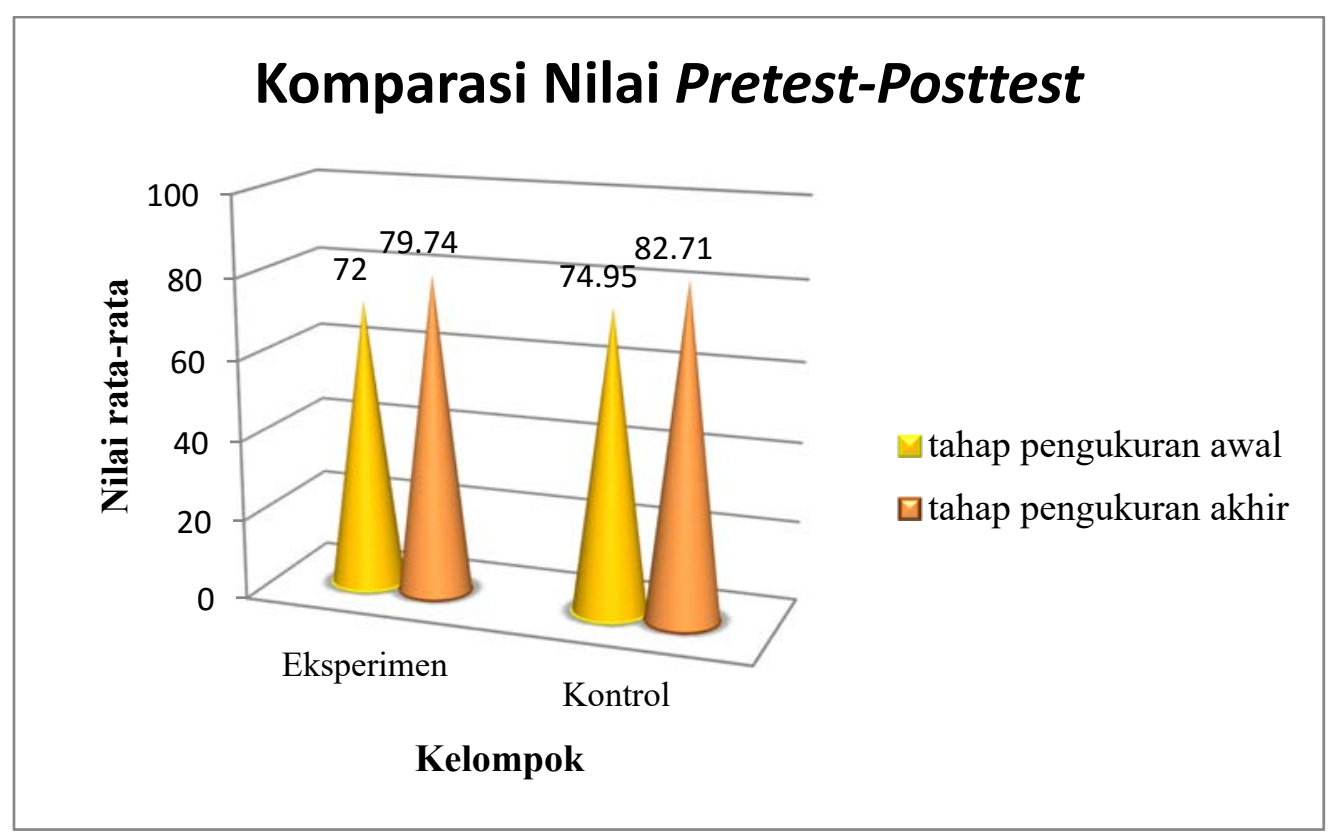

Gambar 4. Grafik Deskripsi Komparasi Hasil Pengukuran Kelompok Eksperimen dan Kelompok Kontrol SD Swasta (SDIP H. Soebandi)

Gugus Maruto 
Keefektifan Model Pembelajaran Kooperatif tipe Group Investigation (GI) Dan Inquiry (Supriyati \& Mawardi)

\section{Hasil Uji Perbedaan Rerata Hasil Belajar}

Sebelum melakukan uji t (uji beda rata-rata) terlebih dahulu dilakukan uji normalitas dan homogenitas sebagai prasyarat yang harus dipenuhi. Berdasarkan hasil uji normalitas menggunakan Kolmogorov-Smirnov yang dikenakan pada data nilai pretest dan posttest dari SD imbas maupun swasta, diperoleh hasil yang menunjukkan angka signifikansi $>0,05$ sehingga persebaran data berdistribusi normal. Uji homogenitas terhadap data nilai pretest dan posttest dari SD imbas maupun swasta juga menunjukkan angka signifikansi $>0,05$ sehingga dapat dikatakan bahwa data kelompok kontrol maupun kelompok eksperimen homogen atau memiliki varian yang sama. Hasil uji t terhadap nilai posttest dan gain score ditunjukkan pada tabel berikut.

\section{Tabel 2. Hasil Uji t Nilai Posttest Kelompok Eksperimen dan Kelompok Kontrol SD Gugus Maruto}

\begin{tabular}{|c|c|c|c|c|c|c|c|c|c|c|}
\hline & \multicolumn{2}{|c|}{$\begin{array}{c}\text { Levene's Test } \\
\text { for Equality } \\
\text { of Variances }\end{array}$} & \multicolumn{7}{|c|}{ t-test for Equality of Means } \\
\hline & & \multirow[t]{2}{*}{$\mathrm{F}$} & \multirow[t]{2}{*}{ Sig. } & \multirow[t]{2}{*}{$\mathrm{t}$} & \multirow[t]{2}{*}{ df } & \multirow[t]{2}{*}{$\begin{array}{c}\text { Sig. } \\
(2- \\
\text { tailed })\end{array}$} & \multirow[t]{2}{*}{\begin{tabular}{l|} 
Mean \\
Diffe \\
rence
\end{tabular}} & \multirow[t]{2}{*}{$\begin{array}{l}\text { Std. } \\
\text { Error } \\
\text { Differe } \\
\text { nce }\end{array}$} & \multicolumn{2}{|c|}{$\begin{array}{c}95 \% \\
\text { Confidence } \\
\text { Interval of the } \\
\text { Difference } \\
\end{array}$} \\
\hline & & & & & & & & & Lower & Upper \\
\hline $\begin{array}{l}\text { nilai } \\
\text { posttest }\end{array}$ & $\begin{array}{l}\text { Equal } \\
\text { variances } \\
\text { assumed } \\
\text { Equal } \\
\text { variances } \\
\text { not assumed }\end{array}$ & ,261 & 610 & $\begin{array}{l}-1,182 \\
-1,185\end{array}$ & $\begin{array}{r}95 \\
\\
93, \\
909\end{array}$ & 240 & $\begin{array}{r}- \\
2,992 \\
74 \\
- \\
2,992 \\
74\end{array}$ & $\begin{array}{r}2,5318 \\
0 \\
2,5247 \\
1\end{array}$ & $\begin{array}{r}- \\
8,018 \\
99 \\
- \\
8,005 \\
67\end{array}$ & $\begin{array}{r}2,033 \\
52 \\
2,020 \\
20\end{array}$ \\
\hline
\end{tabular}

Berdasarkan uji t (uji beda rata-rata) yang telah dilakukan terhadap nilai posttest dan gain score kelompok kontrol dan eksperimen SD Gugus Maruto diperoleh hasil yaitu nilai t hitung $-1,182$ dan t tabel 1,985 dengan signifikansi/probabilitas 0,240 yang dikenakan pada nilai posttest, sedangkan nilai t hitung 0,468 dan $t$ tabel 1,985 dengan signifikansi/probabilitas 0,641 yang dikenakan pada nilai gain score. Karena angka signifikansi/probabilitas dari hasil uji t yang dikenakan pada nilai posttest maupun gain score menunjukkan nilainya $>0,05$ dan nilai $\mathrm{t}$ hitung $<\mathrm{t}$ tabel maka $\mathrm{H}_{0}$ diterima yaitu tidak ada perbedaan hasil belajar yang signifikan dalam 
penerapan model pembelajaran kooperatif tipe Group Investigation dan Inquiry ditinjau dari hasil belajar IPA siswa kelas V SD Gugus Maruto Bawen.

\section{Tabel 3. Hasil Uji t Nilai Gain Score Kelompok Eksperimen dan Kelompok Kontrol SD Gugus Maruto}

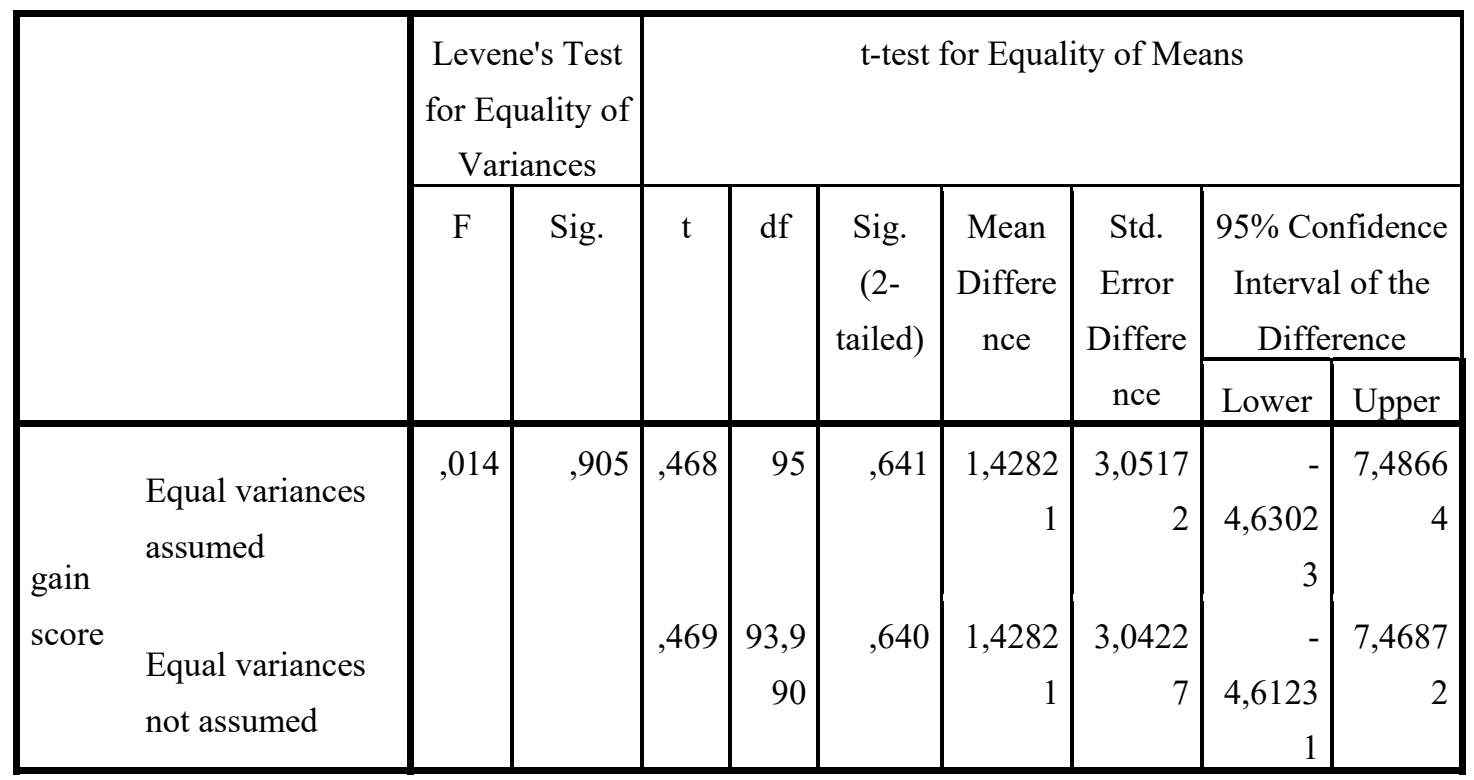

\section{Pembahasan Hasil Penelitian}

Berpijak pada rumusan masalah di SD Gugus Maruto yaitu apakah terdapat perbedaan keefektifan model pembelajaran Group Investigation (GI) dengan model pembelajaran Inquiry ditinjau dari hasil belajar IPA pada siswa kelas V SD Gugus Maruto Bawen, maka dilakukanlah penelitian tentang keefektifan penggunaan kedua model pembelajaran tersebut melalui pelaksanaan proses pembelajaran IPA di kelas $\mathrm{V}$ materi jenis-jenis tanah dengan diberikan perlakuan yang berbeda. Perlakuan dengan menggunakan model Group Investigation diberikan kepada kelompok eksperimen, sedangkan perlakuan dengan menggunakan model Inquiry diberikan kepada kelompok kontrol.

Berdasarkan hasil observsi tingkat ketercapaian guru dalam melaksanakan model Group Investigation pada kelompok eksperimen di SD Negeri Imbas mencapai $90 \%$ dan di SD Swasta mencapai $79 \%$ dari 19 poin kegiatan. Sedangkan hasi observasi pada pelaksanaan proses pembelajaran dengan perlakuan model Inquiry, didapatkan ketercapaian guru dalam melaksanakan sintak lebih tinggi yaitu 
Keefektifan Model Pembelajaran Kooperatif tipe Group Investigation (GI) Dan Inquiry (Supriyati \& Mawardi)

mencapai 91\% untuk SD Negeri Imbas dan 87\% untuk SD Swasta dari 22 poin kegiatan.

Berdasarkan persentase ketercapaian guru melaksanakan kegiatan dalam sintak model Group Investigation dan Inquiry tersebut, nampak bahwa tingkat ketercapaian pelaksanaan model Inquiry lebih tinggi. Hal ini dimungkinkan karena sintak dari model Inquiry lebih rinci dan mudah dalam pelaksanaannya.

Berdasarkan hasil penelitian yang telah dilakukan di SD Gugus Maruto pada bulan Februari-April 2015, diperoleh nilai rata-rata posttest untuk kelompok eksperimen dari SD Negeri Imbas sebesar 71,38 sedangkan untuk kelompok kontrol sebesar 74,59. Tidak jauh berbeda, nilai rata-rata posttest untuk kelompok eksperimen dari SD Swasta sebesar 79,73 sedangkan untuk kelompok kontrol sebesar 82,71. Dalam pelaksanaan uji t hasil posttest kelompok eksperimen dari SD Negeri Imbas dan Swasta dijadikan satu, begitu pula dengan kelompok kontrol sehingga diperoleh nilai rata-rata dari kelompok eksperimen yaitu 74,91 dan kelompok kontrol 77,90. Hasil perolehan posttest tersebut selanjutnya dikenakan uji $\mathrm{t}$ untuk mengetahui ada/tidaknya perbedaan yang signifikan dari perlakuan kedua model tersebut.

Hasil dari uji t yang telah dilakukan terhadap nilai posttest dari kelompok eksperimen dan kelompok kontrol SD Gugus Maruto menunjukkan bahwa $\mathrm{H}_{0}$ diterima, karena nilai signifikansi/probabilitas $>0,05$ dan nilai $t$ hitung $<\mathrm{t}$ tabel. Nilai t hitung sebesar $-1,182$ dan $\mathrm{t}$ tabel 1,985 dengan signifikansi/probabilitas 0,240 . Tanda negatif pada t hitung dikarenakan kelompok kontrol memperoleh nilai rata-rata lebih unggul daripada kelompok eksperimen.

Pelaksanaan uji t tidak hanya dikenakan pada nilai posttest saja, tetapi juga dikenakan pada nilai gain score yang diperoleh dari selisih nilai posttest-pretest. Hal ini dikarenakan ada anggapan bahwa nilai gain score lebih berarti untuk di uji $t$ dari pada nilai posttest saja, karena nilai gain score menunjukkan hasil dari proses pembelajaran yang dilihat dari seberapa besar selisih nilai yang diperoleh pada tahap akhir-tahap awal. Sedangkan apabila hanya dikenakan pada nilai posttestnya saja dianggap kurang berarti karena bisa saja adanya perbedaan disebabkan oleh faktor internal siswa seperti tingkat kecerdasan siswa dalam suatu sekolah memang tinggi.

Hasil uji t terhadap nilai gain score kelompok eksperimen dan kelompok kontrol SD Gugus Maruto menunjukkan t hitung sebesar 0,468 dan t tabel sebesar 1,985 dengan signifikansi/probabilitas 0,641 . Karena nilai t hitung $<\mathrm{t}$ tabel $(0,648<$ 1,985) dan nilai signifikansi/probabilitas $0,641>0,05$ maka $\mathrm{H}_{0}$ diterima. Sehingga dapat dilihat bahwa hasil uji $\mathrm{t}$ baik yang dikenakan pada nilai posttest maupun gain score menunjukkan bahwa $\mathrm{H}_{0}$ diterima.

$\mathrm{H}_{0}$ diterima, artinya tidak ada perbedaan hasil belajar yang signifikan dalam penerapan model pembelajaran kooperatif tipe Group Investigation dan Inquiry 
ditinjau dari hasil belajar IPA siswa kelas V SD Gugus Maruto Bawen. Karena tidak ada perbedaan yang signifikan, maka dapat disimpulkan bahwa model Group Investigation dan Inquiry efektif digunakan dalam pembelajaran IPA di kelas V SD Gugus Maruto. Dikatakan efektif karena kelompok eksperimen dan kelompok kontrol telah mencapai kriteria ketuntasan belajar secara klasikal yaitu 85\% siswa tuntas dengan KKM 65. Hasil ketuntasan belajar kelompok eksperimen SD Gugus Maruto mencapai $87 \%$ dengan 6 siswa tidak mencapai KKM. Sedangkan untuk kelompok kontrol SD Gugus Maruto diperoleh hasil ketuntasan belajar mencapai 90\% dengan 5 siswa tidak mencapai KKM.

\section{SIMPULAN DAN SARAN}

Berdasarkan hasil analisis data yang telah dibahas pada bab IV dapat disimpulkan bahwa tidak ada perbedaan hasil belajar yang signifikan dalam penerapan model pembelajaran kooperatif tipe Group Investigation dan Inquiry ditinjau dari hasil belajar IPA siswa kelas V SD Gugus Maruto Bawen. Sehingga model pembelajaran Group Investigation dan Inquiry efektif digunakan dalam pembelajaran IPA di kelas V SD Gugus Maruto. Berpijak dari simpulan penelitian tersebut di atas, disarankan dalam proses pembelajaran, guru sebagai salah satu pemangku kepentingan dalam pendidikan menggunakan model pembelajaran kooperatif Group Investigation atau Inquiry dalam pembelajaran IPA sebagai alternatif untuk meningkatkan hasil belajar siswa. Pemilihan model Group Investiation atau Inquiry disesuaikan dengan karakteristik dan kebutuhan siswa.

\section{DAFTAR PUSTAKA}

Joyce, B., Calhoun, E., \& Weil, M. 2009. Models of Teaching (terjemahan). Yogyakarta: Pustaka Pelajar.

Karnawati. 2013. Perbedaan Hasil Belajar Matematika Menggunakan Model Kooperatif Tipe Student Team Achievement Division (STAD) dan Model Kooperatif Tipe Group Investigation (GI) pada Siswa Kelas X SMK PGRI 2 Salatiga Tahun Pelajaran 2012/2013. Skripsi. Salatiga: Universitas Kristen Satya Wacana.

Mawardi \& Puspasari. 2011. Perbedaan Efektivitas Pembelajaran Kooperatif Tipe Jigsaw dengan Pembelajaran Konvensional. Scholaria Jurnal Ilmiah Pendidikan Ke-SD-an . Salatiga: Widya Sari Press.

Permendiknas No.22 Tahun 2006 tentang Standar Isi. 
Keefektifan Model Pembelajaran Kooperatif tipe Group Investigation (GI) Dan Inquiry (Supriyati \& Mawardi)

Setyorini, R. 2014. Pengaruh Model Pembelajaran Kooperatif Tipe Group Investigation Terhadap Hasil Belajar Matematika pada Materi Segiempat Siswa Kelas VII SMP Negeri 2 Kledung Semester II Tahun Pelajaran 2012/2013. Skripsi . Salatiga: Universitas Kristen Satya Wacana.

Soewarso. 2013. Pengembangan Pembelajaran Ilmu Pengetahuan Sosial Sekolah Dasar. Semarang: UNNES.

Sudjana, N. 2005. Penilaian Hasil Proses Belajar Mengajar. Bandung: Remaja Rosdakarya.

Utami, P. 2012. Perbedaan Hasil Belajar Matematika Antara Siswa yang Diajar Melalui Model Cooperative Learning Tipe GI dengan Tipe NHT pada Kelas VII SMP N 10 Salatiga. Skripsi. Salatiga: Universitas Kristen Satya Wacana. 